\title{
Identification of active component in red pomegranate (punica granatum L.) seeds ethanolic extract
}

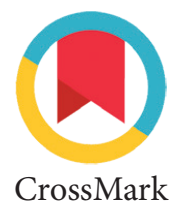

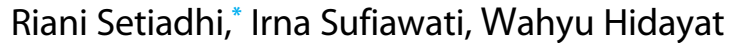

Abstract

Objective: Pomegranate (punica granatum I.) have many benefits for health and used as traditional medicine. The pomegranate seeds are rich in antioxidants, namely flavonoids and tannins as well as alkaloid which is an antibacterial. The Aim of this study was to identify the pure isolate/active component of red pomegranate seeds ethanolic extract.

Material and Methods: Two-ways TLC of the purified crystals which were obtained from the hexan fraction of ethanolic extract red pomegranate seeds, were used to make sure there was only 1 active compound of red pomegranate seeds. The isolate was identified using dragendorff, $\mathrm{Mg}$ and $\mathrm{HCl}, \mathrm{NaOH}$, Bunchard, Lieberme using dragendorff, $\mathrm{Mg}$ and $\mathrm{HCl}, \mathrm{NaOH}$, Bunchard, Liebermen, $\mathrm{FeCL}_{3}$ and $\mathrm{HCl}$ concentrated reagents.

Results: Isolate identification test using dragendorf reagents showed positive result (an orange-coloured).

Conclusion: The pure isolate/active component of red pomegranate seeds is alkaloid.
Department of Oral Medicine, Faculty of Dentistry, Padjadjaran University, Yogyakarta, Indonesia
*Correspondence to: Riani Setiadhi, Department of Oral Medicine, Faculty of Dentistry, Padjadjaran University, Yogyakarta, Indonesia riani.setiadhi@fkg.unpad.ac.id

Received: 19 February 2019 Revised: 25 February 2019

Accepted: 20 March 2019

Available Online 1 August 2019

Keywords: Active component, Alkaloid, Ethanolic extract red pomegranate seeds

Cite this Article: Setiadhi R, Sufiawati I, Hidayat W. 2019. Identification of active component in red pomegranate (punica granatum I.) seeds ethanolic extract. Journal of Dentomaxillofacial Science 4(2): 83-86. D01:10.15562/ jdmfs.v4i2.934

\section{Introduction}

Pomegranate (punica granatum 1.) is a versatile fruit that can be consumed as fresh fruit or is used as raw material for food processing, such as sauces, jellies, jams and juices. Pomegranate have the health promoting effect in the traditional medicines. Fruits, seeds, peel and leaves of pomegranate contain numerous important ingredients and such ingredients show therapeutics importance in curing the disease. A large number of evidences based on laboratory research revealed that pomegranate fruits, peels and seeds show effective role in diseases cure through the modulation of numerous biological activities..$^{1-8}$

The pomegranate seeds are rich in antioxidants, namely flavonoids and tannins as well as alkaloid which is an antibacterial. Plants products or ingredients of seeds, flowers, stem, bark and leaves show very effective role in the inhibition of growth of pathogens. Plants are one of the good sources of secondary metabolites including tannins, triterpenoids, alkaloids, flavonoids and glycosides, which confirmed antimicrobial activities in vivo. ${ }^{9,10}$ Punica granatum shows a very effective role in the inhibition of microorganism growth. ${ }^{8}$ The phytochemical screening proved that pomegranate seeds extract contains phenolic, flavonoids, alkaloids, saponins and tannins. ${ }^{11}$

Alkaloids are an alkaline organic containing nitrogen (N) generally derived from plants as the secondary metabolism, commonly found in the leaves, twigs, seeds, and bark. Alkaloids have strong physiological effects on humans. In pharmacology, the use of alkaloid compounds is to stimulate the nervous system, increasing blood pressure, relieving pain, antibacterial, tranquilizer, etc. ${ }^{12-15}$

The aim of this study was to identify the active compounds of red pomegranate seeds (Punica granatum L.).

\section{Material and Methods}

This study was an experimental laboratory, conducted at the Laboratory of Pusat Antar Universitas Bandung Institute of Technology.

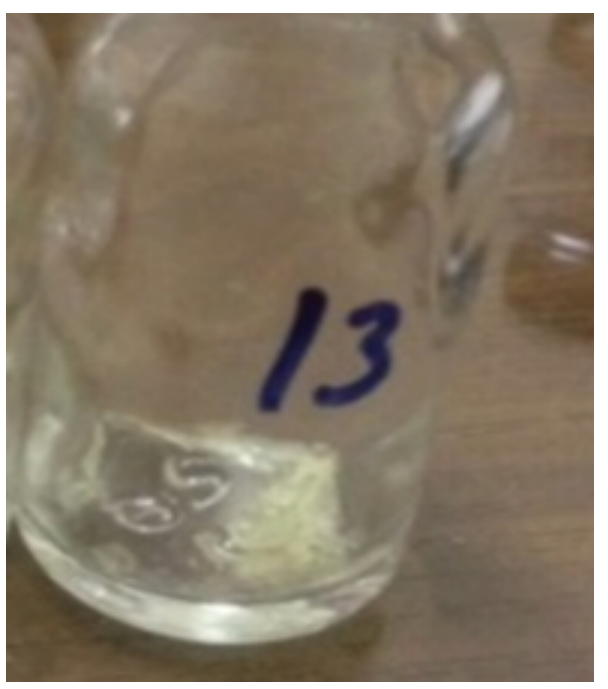

Figure 1 Active compound crystals from red pomegranate seed extract 
The fresh red pomegranate were collected from Sindang Anom Garut, peeled off, blended, filtered, dried for $2 \times 24$ hours at $48^{\circ} \mathrm{C}$, mashed into powder and subjected to maceration process using $96 \%$ ethanol to get concentrated crude extract.

Fractionation was done in order to separate the compounds of the extract, using N-hexan (non-polar), ethyl Acetate (semi polar) and 10\% ethanol (polar) as the solvents, to analize the hexan, ethyl acetate and ethanol concentrated fraction, TLC was performed on a kiesel gel 254 GF plate (e. merck) with the developing system of hexan: ethyl acetate: formic acid $(1: 1: 0,1)$ mixture and a UV light spot viewer with 254 wavelength emissions.

The crystals were washed using isopropyl alcohol so that the pollutant dissolved. After the solvent evaporated, the pure crystals left behind. The crystals were monitored with TLC on a kiesel gel 254 GF plate (e. Merck) and using a UV light spot viewer with 366 wavelength emissions to identify the spot.

To make sure that there was only 1 active compound, purification test with two- ways TLC was done using hexane: ethyl Acetate: formic acid (1:1:0.1) mixture as the eluents for the first development, and the second development using chloroform: methanol: acetate acid (9:0.5:0.5) mixture as the eluents.

To determine the active compound of red pomegranate seed extract by identifying it using reagents that can provide the characteristics of each group.

Identification methods: alkaloid identification; a few drops of dragendorff's reagents was added into a test tube containing isolate and the colour developed was noticed. Appearance of orange colour indicates the presence of alkaloids. ${ }^{15-18}$ Flavonoid identification; a few magnesium turnings and 2 drops of concentrated $\mathrm{HCl}$ were added to the isolate in a test cube. The formation of red colour showed the presence of flavonoid. ${ }^{16-19}$ Quinone identification; $1 \mathrm{ml}$
$\mathrm{NaOH}$ or $\mathrm{KOH}$ was added into a test tube containing isolate. A change of the colour indicating the presence of quinone. ${ }^{16,19}$ Steroid identification; liebermen bunchard reagent $(1 \mathrm{ml}$ of glacial acetic acid and $1 \mathrm{ml}$ of acetic anhydride and two drops of concentrated sulphuric acid) were added into a test tube containing isolate. The solution become red, then blue and finally bluish green indicated the presence of steroid. ${ }^{16,19}$ Tannin identification; ferric chloride $\left(\mathrm{FeCl}_{3}\right)$ was added into a test tube containing isolate, formation of a black or brown colour showed the presence of tannins. ${ }^{16,19}$ Saponins identification; $\mathrm{HCl}$ was added into a test tube containing isolate, shaken vigorously. Copious lather formation indicated the presence of saponins. ${ }^{16,19}$

\section{Results}

Only 1 active compound in the purified crystals which were obtained from the hexan fraction of ethanolic extract red pomegranate seeds and was confirmed again through two-ways TLC.

To determine the active compound of red pomegranate seed extract figure 1, the isolate/active compound was identified using different reagents as follows: test for alkaloids; using dragendroff's reagent, the appearance of orange colour indicates the presence of alkaloids figure 2A. Test for flavonoid; using $\mathrm{Mg}$ dan concentrated $\mathrm{HCl}$, the absence of red colour indicated no flavonoids figure $2 \mathrm{~B}$. Test for quinones; using $\mathrm{NaOH}$ or $\mathrm{KOH}$, the absence of colour change indicating no quinones figure 2C. Test for saponins; using $\mathrm{HCl}$, no copious lather formation indicated the absence of saponins figure 2D. Test for tannin; using Ferric chloride $\left(\mathrm{FeCl}_{3}\right)$, the absence of a black or brown colour formation indicated no tannin figure 2E. Test for steroid; using Ferric chloride $\left(\mathrm{FeCl}_{3}\right)$, no formation of a black or brown colour indicated no steroid figure $2 \mathrm{~F}$.
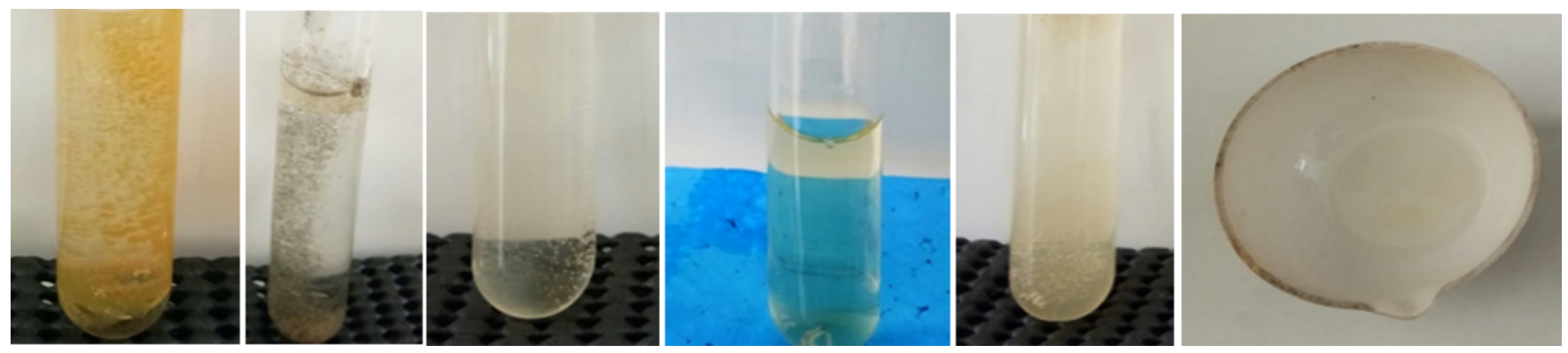

Figure 1 A. The appearance of orange colour, B. Test result for flavonoids, C, Test result for quinones, D. Test result for saponins, E. Test result for tannin, F. Test result for steroid 


\section{Discussion}

The appearance of orange colour in the alkaloid identification of red pomegranate seed extract isolates/active compound, indicates that the active isolates was the alkaloids. Whereas in the flavonoid, quinones, saponins, tannin and steroid identifications indicate none of those phytoconstituents were in the isolate.

The phytochemical screening of pomegranate seeds extract showed positive result for phenolic, flavonoids, steroids, alkaloid, saponnins and tannins ${ }^{11}$ but in fact the red pomegranate seed extract isolates/active compound only contain alkaloids which can act as antibacterials. The alkaloid compounds containing one or more nitrogen atoms are usually in the form of a combined, most are part of a cyclic system. ${ }^{16}$

According to Jouvenaz et al. ${ }^{20}$ and Karou. ${ }^{21}$ alkaloids can inhibit the growth of gram-positive bacteria and gram-negative. The ability of alkaloid compounds as antibacterial by interfering the components of peptidoglycan in bacterial cells, so that the cell wall layer is not completely formed and lead the death of these cells. ${ }^{16,20-23}$

Alkaloids extracted from plants act through downregulation and inhibition of efflux pump ATPases causes disruption of the ABC transporters an the bacterium and reduce oxygen consumption. This cause disruption of bacterial homeostasis and further compromises the outer membrane and cytoplasmic membrane integrity of the bacterium. At last, the series of inhibitions and disruption causes leakage of cytoplasmic contents leading to antimicrobial activity. ${ }^{24}$

\section{Conclusion}

The pure isolate/active component of red pomegranate seeds is alkaloid which is an antibacterial.

\section{Acknowlegment}

The researchers like to thank to the Ministry of Research, Technology and Higher Education for this immense opportunity and for funding provided for us to conduct this study and to all laboratory workers at the Laboratory of Pusat Antar Universitas Bandung Institute of Technology for helping us in conducting this research.

\section{Conflict of Interest}

All authors confirm that there is no conflict of interest associated with this publication.

\section{References}

1. Marhari OY, Dewi KK. Khasiat ajaib delima. 1st ed. Jakarta: Padi; 2014. p. 1-5, 23-24, 63.

2. Narayan T, Deshpande S, Jha A, et al. Punica granatum (Pomegranate) fruit and its relevance in Oral Hygiene. J Dent Med Sci 2014;13: 29-34.

3. Jurenka J. Therapeutic applications of pomegrante (punica granatum L.): a review. Alt Med Review 2008;13: 128-131, 137-138, 141

4. Gumienna M, Szwengiel A, Gorna, B. Bioactive components of pomegranate fruit and their transformation by fermentation processes. Eur Food Res Technol 2016;242: 631-640.

5. Viuda-Martos M, Fernandez-Lopez J, Perez-Alvarez JA. Pomegranate and its many functional components as related to human health: a review. Comp Reviews Food Sci \& Food Safety 2010;9: 635-654.

6. Bhandari PR. Pomegranate (punica granatum L). Ancient seeds for modern cure? Review of potential therapeutic applications. Int J Nutr Pharm, Neurol Disea 2012;2: 171-184.

7. Kumar KA, Vijayalakshmi K. In vitro anti-microbial activity and phytochemical analysis of selected fruit wastes. Int J Curr Microbiol App Sci 2013;2: 196-204.

8. Rahmani AH, Alsahli MA, Almatroodi SA. Active constituents of pomegranates (punica granatum) as potential candidates in the management of health through modulation of biological activities. Pharm J 2017;9: 689-695.

9. Dahanukar SA, Kulkarni RA, Rege NN. Pharmacology of medicinal plants and natural products. Indian J Pharm 2000;32: 81-118.

10. Cowan MM. Plant products as antimicrobial agents. Clin Microbiol Reviews 1999;12: 564-582.

11. Setiadhi R, Sufiawati I, Zakiawati D, et al. Inhibition growth of pomegranate seeds extract against streptococcus sanguis: the cause of recurrent aphthous stomatitis. J Dentomaxillofac Sci 2017;2: 7-11.

12. Ajizah A. Sensitivitas salmonella typhimurium terhadap ekstrak daun psidium guajava L. Bioscient 2004;1: 31-38.

13. Wullur AC, Schaduw J, Wardhani ANK. Identifikasi alkaloid pada daun sirsak (annona muricataL.). JIF 2012;3: 54-56.

14. Pasaribu SP. Uji Boaktivitas Metabolit Sekunder dari Daun Tumbuhan Babandotan (Ageratum conyzoides L.). J Kimia Mulawarman 2009;6: 23-29.

15. Riska A, Weny JA, Musa LaA. Identifikasi senyawa alkaloid dari ekstrak metanol kulit batang mangga (mangifera indica L). J Entropi 2013;8: 514-519.

16. Olasupo AD, Aborisade AB, Olagoke OV. Phytochemical analysis and antibacterial activities of Spinach Leaf. Am J Phytomedic Clin Therap 2018;2: 1-4.

17. Narender B, Himabindu P. Phytochemical analysis and evaluation of in vitro antioxidant activity of punica granatum L. Int J Pharm Phytochem Res 2017;9; 1110-1118.

18. Hammado N, Illing I. Identifikasi senyawa bahan aktif alkaloid pada tanaman lahuna (eupatorium odoratum). J Dinamika 2013;4: 1-18.

19. Elaleem HGA, Albasheer AA, Elaleem KGA. Phytochemical screening and antibacterial activity of punica granatum fruit rind extracts. Glob J Med Plant Res 2016;4: 9-15.

20. Jouvenez DP, Blum MMS, Maccconel JB. Antibacterial activity of fenom alkaloid from the imported fire and solepncsis invicta buren. Am Soc Microbiol 1972;2: 291-293. 
21. Karou D, Aly S, Antonella CS, et al. Antibacterial activity of fenom alkaloid from the imported fire and solepncsis invicta buren. Am Soc Microbiol 2006;2: 291-293.

22. Kurniawan B, Aryana WF. Binahong (cassia alata L) as inhibitor of escherichia coli growth. J Majority 2015;4: 100-104

23. Darsana IGO, Besung INK, Mahatmi H. Potensi daun binahong (anredera cordifolia (tenore) steenis) dalam menghambat pertumbuhan bakteri escherichia coli secara in vitro. Ind Medic Veterinus 2012;1: 337-351
24. Cushnie TT, Cushnie B, Lamb AJ. Alkaloids: an overview of their antibacterial, antibiotic-enhancing and antivirulence activities. Int $\mathrm{J}$ Antimicrob Agents 2015;44: 377-386.

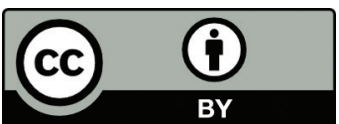

This work is licensed under a Creative Commons Attribution 